\title{
Możliwości poprawy odporności na erozję kawitacyjną staliwnych zaworów hydraulicznych
}

\author{
A possibility to improve resistance of cast-steel hydraulic \\ valves to cavitation erosion
}

\section{Streszczenie}

Powierzchnie wewnętrzne gniazd uszczelniająco-odwadniających zaworów hydraulicznych są zwykle odwzorowane przez wkładki wykonane ze stopu miedzi, które są mechanicznie połączone z korpusem zaworu. Wskutek gwałtownych zmian ciśnienia wody, wkładki te mogą ulec poluzowaniu, co powoduje nieszczelność zaworów. W pracy zaproponowano nowe rozwiązanie poprzez zastosowanie powłoki natryskiwanej plazmowo. Przedstawiono wyniki badań odporności na erozję kawitacyjną dotychczas stosowanego materiału wkładki ze stopu CuZn39Pb2Al oraz materiału powłoki wykonanej z proszku WCCoCr 86104. Oceniono strukturę geometryczną powierzchni kraterów kawitacyjnych (parametr $\mathrm{R}_{\mathrm{t}}$ ). Stwierdzono, że powłoka naniesiona plazmowo charakteryzuje się zdecydowanie wyższą odpornością na erozję kawitacyjną, w porównaniu do dotychczas stosowanego materiału wkładki ze stopu CuZn39Pb2Al.

Słowa kluczowe: zawory hydrauliczne; zużycie kawitacyjne; powłoka natryskiwana plazmowo

\begin{abstract}
Inner surfaces of sealing-draining seats in hydraulic valves are usually reproduced by inserts made of a copper alloy joined mechanically with valve housing. As a result of sudden variations in water pressure, they can be subject to loosening which leads to deterioration of valve tightness. In the paper, a new solution is proposed for finishing surfaces of valve seats by application of a plasma-sprayed coating. The solution is validated by results of cavitation erosion resistance test performed for both the CuZn39Pb2Al alloy used earlier for the inserts and the material of coating made of WCCoCr 86104 powder. The resistance assessment was based on geometrical structure of cavitation craters (parameter $R_{t}$ ). It has been found that the plasma-sprayed coating demonstrated a definitely higher resistance to cavitation erosion compared to CuZn39Pb2Al alloy used earlier for valve seat inserts.
\end{abstract}

Keywords: hydraulic valves; cavitation wear; plasmasprayed coating

\section{Wstęp}

Erozja kawitacyjna występuje w elementach instalacji hydraulicznych, których powierzchnie mają styczność z wodą przepływającą z dużą prędkością, w takich jak łopatki, czy wirniki pomp wodnych [1,2].

Jedną z metod poprawy odporności na erozję kawitacyjną jest zastosowanie napoin wykonanych technikami spawalniczymi, na przykład napawaniem laserowym, napawaniem w atmosferze gazów ochronnych, czy napawaniem plazmowym [3,4]. Jednak zastosowanie spawalniczej techniki wiąże się z ryzykiem wystąpienia pęknięć spawalniczych w obszarze nadtopień lub w strefie wpływu ciepła $[5,6]$. Problem ten nie występuje w przypadku kształtowania powłok metodą natryskiwania plazmowego, np. VPS, APS, czy HVOF.
Celem pracy była ocena możliwości poprawy odporności na erozję kawitacyjną gniazd uszczelniająco-odwadniających zaworów hydraulicznych poprzez zastosowanie powłoki natryskiwanej plazmowo metodą HVOF.

\section{Materiał i metodyka badań}

Materiałem do badań były próbki ze staliwa G17Mn5 oraz próbki ze stopu CuZn39Pb2Al, stosowanego dotychczas na wkładki gniazd uszczelniająco-odwadniających zaworów hydraulicznych, o wymiarach $20 \times 20 \times 5 \mathrm{~mm}$.

Staliwne próbki do natryskiwania plazmowego proszkiem WCCoCr 86104 odtłuszczono acetonem, a następnie poddano

Prof. dr hab. inż. Antoni W. Orłowicz; dr hab. inż. Marek Mróz, prof. PRz; mgr inż. Magdalena Radoń; mgr inż. Bogdan Kupiec; mgr inż. Magdalena Jacek; mgr inż. Paulina Sobolewska - Politechnika Rzeszowska.

Autor korespondencyjny/Corresponding author: m.radon@prz.edu.pl 
piaskowaniu, w celu rozwinięcia powierzchni, dla zapewnienia lepszej przyczepności powłok do podłoża.

Wyniki badań kształtu, rozmiaru, udziału procentowego i składu chemicznego cząstek proszku WCCoCr 86104 (rys. 1).

Proces natryskiwania plazmowego powłoki na staliwne podłoże wykonano w firmie Thermisches Beschichtungs Center Uskovic $\mathrm{GmbH}$, z wykorzystaniem urządzenia Thermico C-CJS-N HVOF, wyposażonego w podajnik CPF-2 z grawimetrycznym podawaniem proszku oraz $\mathrm{w}$ palnik $\mathrm{K}$ 5.2 z dyszą przyśpieszającą o średnicy $140 \mathrm{~mm}$.

Badania odporności na erozję kawitacyjną wykonano w wodzie destylowanej, z zastosowaniem aparatu Sonics, firmy Vibra-Cell. Częstotliwość drgań wynosiła $20 \mathrm{kHz}$. Odległość czoła głowicy ultradźwiękowej od powierzchni próbki wynosiła 0,5 mm. Czas oddziaływania kawitacyjnego wynosił 120 minut.

Zużycie kawitacyjne próbek oceniono w oparciu o profilogramy wykonane wzdłuż linii przechodzącej przez środek kraterów kawitacyjnych.

Badania makro- i mikrostruktury powłok wykonano z zastosowaniem mikroskopu skaningowego VEGA XMH.

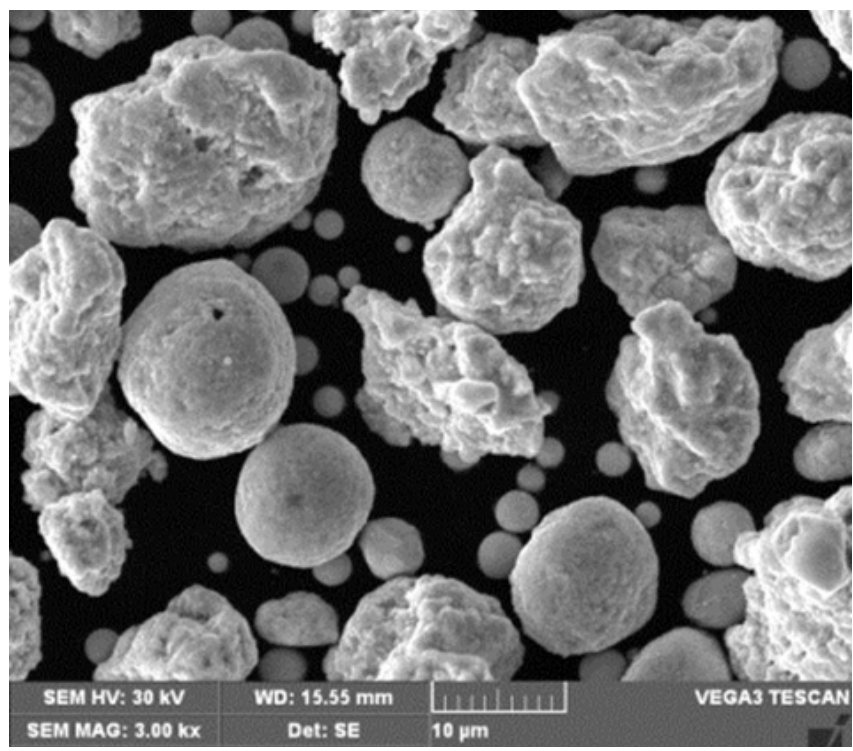

\begin{tabular}{|c|c|c|}
\hline Kształt & Rozmiar, $\boldsymbol{\mu m}$ & Udział, $\%$ \\
\hline kuliste & $10 \div 19$ & 20 \\
& $2 \div 10$ & 20 \\
\hline globularne & $20 \div 30$ & 60 \\
\hline
\end{tabular}

\begin{tabular}{|c|c|c|c|}
\hline \multicolumn{5}{|c|}{ Skład chemiczny, \% } \\
\hline W & Co & Cr & C \\
\hline 80,10 & 10,73 & 3,67 & 5,50 \\
\hline
\end{tabular}

Rys. 1. Schemat integracji elementów stanowiska zrobotyzowanego spawania wiązką laserową

Fig. 1. Results of examination of shape, size, percentage share, and chemical composition of WCCoCr 86104 powder particles
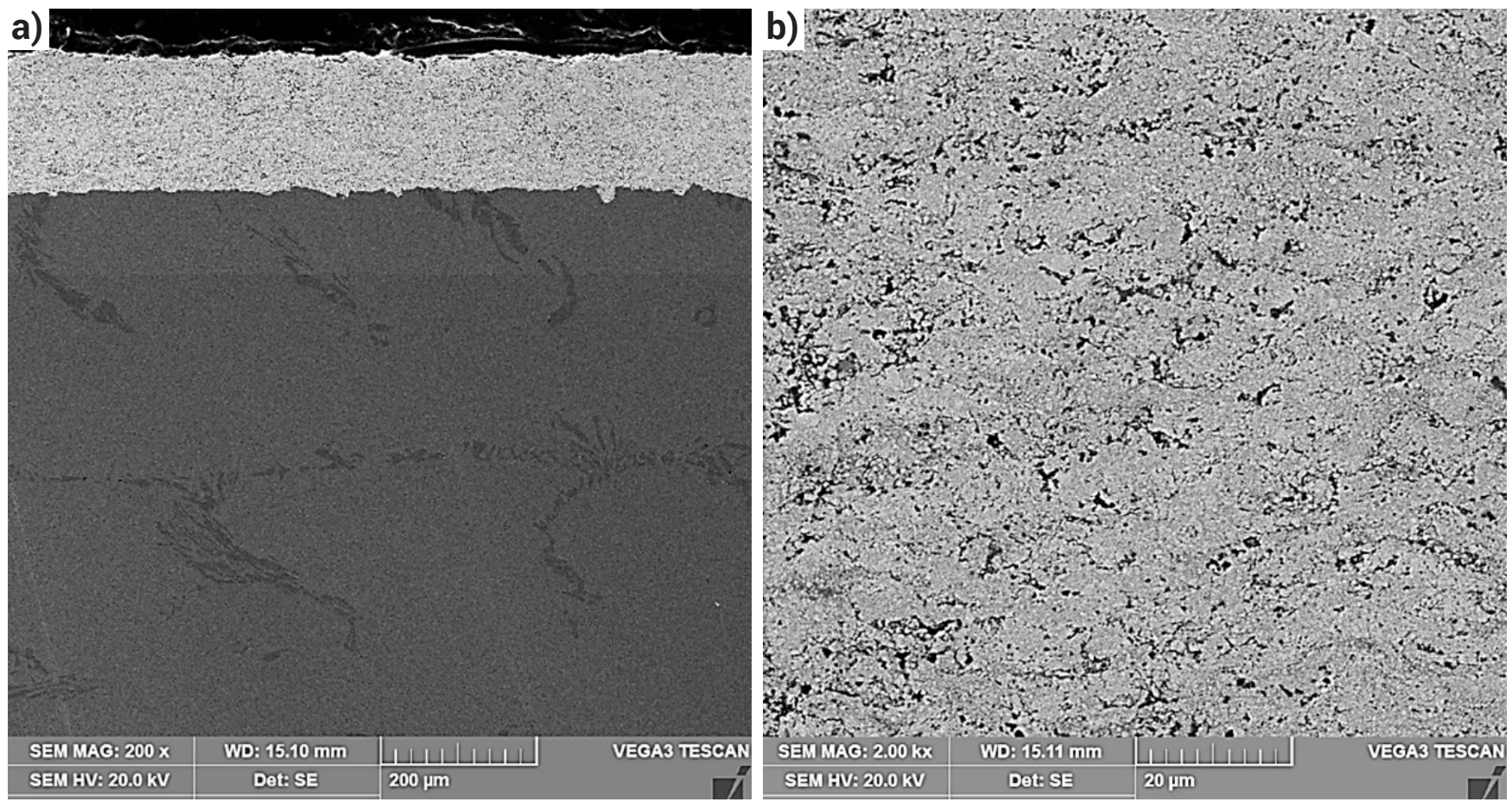

Rys. 2. Makro- (a) i mikrostruktura (b) powłoki wykonanej z proszku WCCoCr 86104

Fig. 2. (a) Macro- and (b) microstructure of a coating made of WCCoCr 86104 powder 


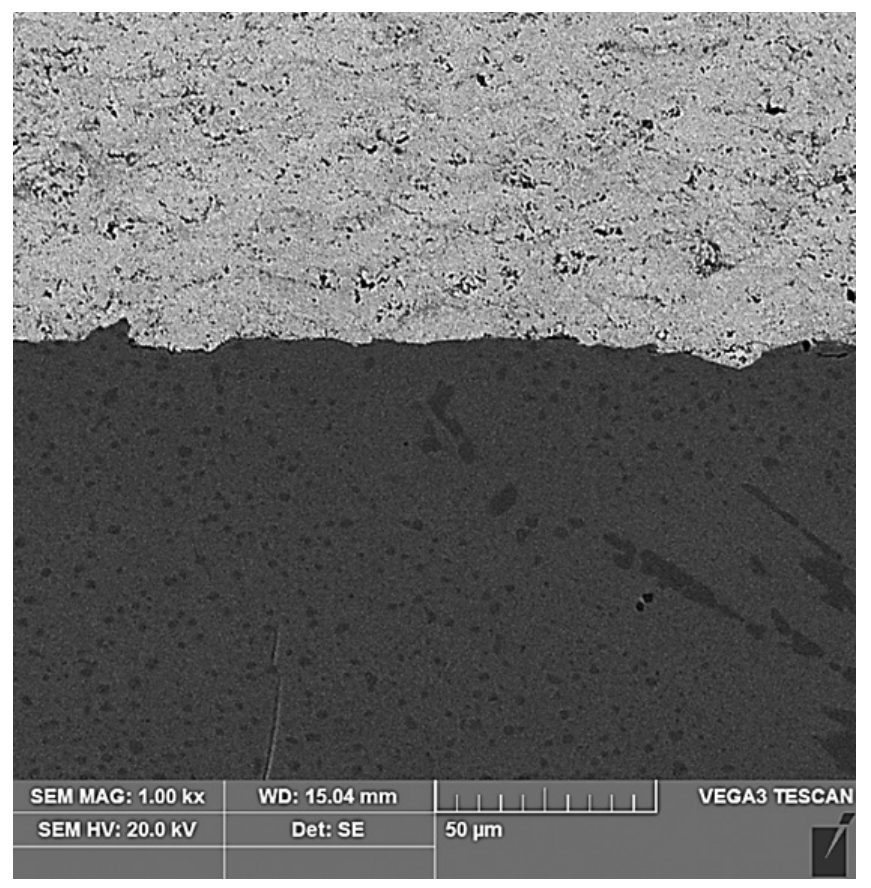

Rys. 3. Widok granicy podłoże staliwne-powłoka WCCoCr 86104 dobra jakość połączenia

Fig. 3. View of the cast-steel substrate-WCCoCr 86104 coating boundary
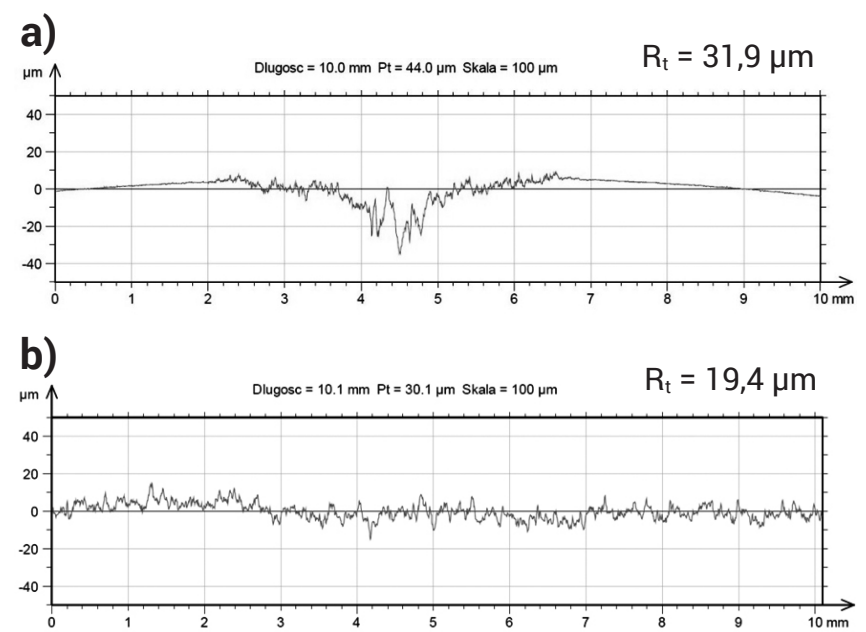

Rys. 4. Przykładowe profilogramy kraterów kawitacyjnych: a) stop CuZn39Pb2Al, b) powłoka WCCoCr 86104

Fig. 4. Example profilograms of cavitation craters: a) CuZn39Pb2Al alloy, b) WCCoCr coating
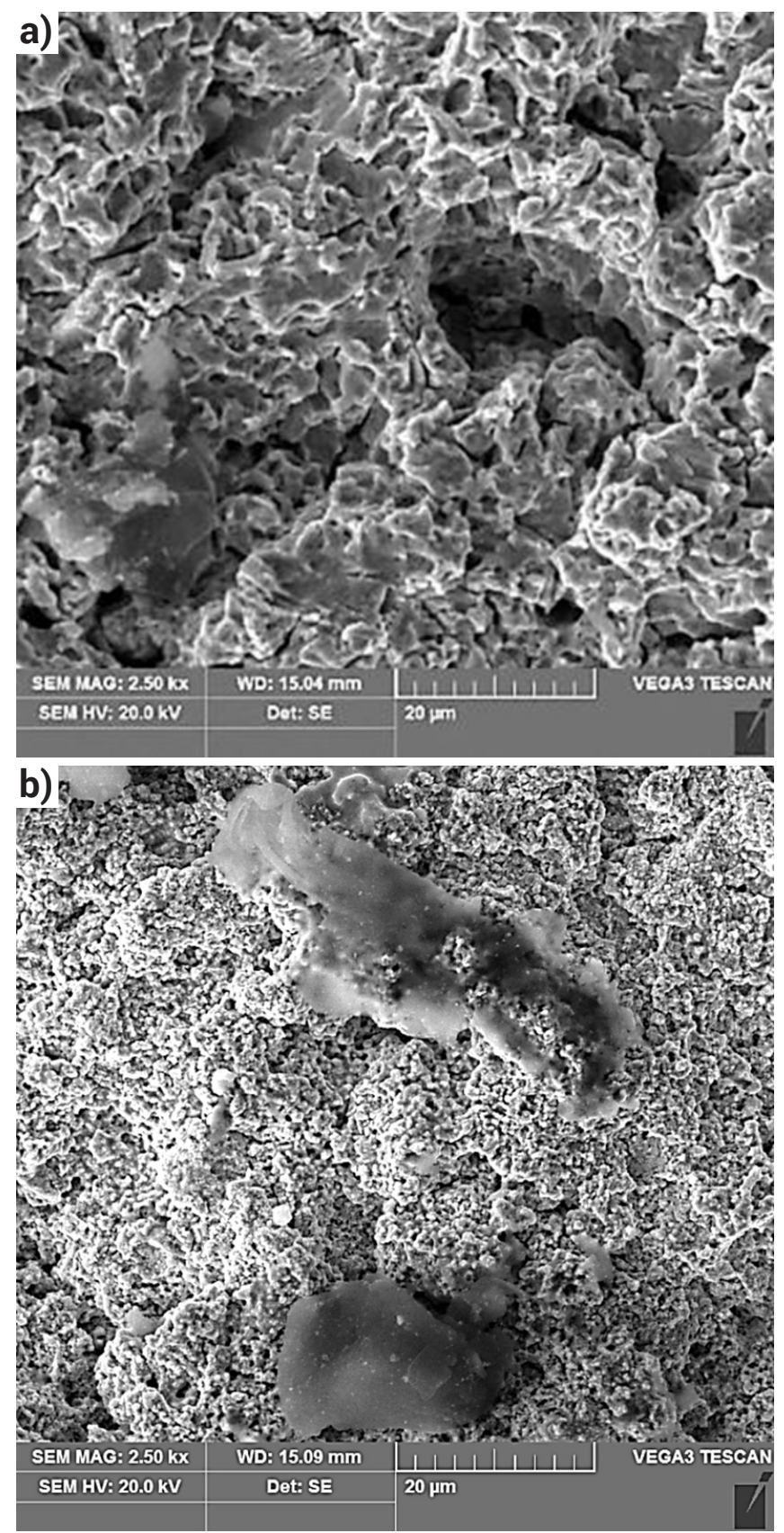

Rys. 5. Widok krateru kawitacyjnego: a) stop CuZn39Pb2Al, b) powłoka WCCoCr 86104

Fig. 5. A view of cavitation crater. a) CuZn39Pb2Al alloy, b) WCCoCr coating

\section{Wnioski}

Uzyskane wyniki badań wskazują, że natryskiwana plazmowo powłoka WCCoCr 86104 charakteryzuje się wyższą odpornością na erozję kawitacyjną niż stop CuZn39Pb2Al, dotychczas stosowany na wkładki gniazda uszczelniająco-odwadniającego zaworów hydraulicznych, co uzasadnia zastosowanie tej technologii w procesie produkcyjnym zaworów.

\section{Literatura}

[1] Kumar P., Saini R.P.: Study of cavitation in hydro turbines - A review, Renewable and Sustainable Energy Reviews, vol. 14, pp. 374-383, 2010.

[2] Dorji U., Ghomashchi R.: Hydro turbine failure mechanisms: an overview, Eng. Fail. Anal., vol. 44, pp. 136-147, 2014

[3] Romo S.A., Santa J.F., Giraldo J.E., Toro A.: Cavitation and high-velocity slurry erosion resistance of welded Stellite 6 alloy, Tribology International, vol. 47, pp. 16-24, 2012.

[4] Kwak C.F., Man H.C., Cheng F.T.: Cavitation erosion-corrosion behaviour of laser surface alloyed AISI 1050 mild steel using NiCrSiB, Materials Science and Engineering, A303, pp. 250-261, 2001.
[5] Malek Ghaini F., Ebrahimnia M., Gholizade Sh.: Characteristics of crack in heat affected zone of ductile cast iron in powder welding process, Engineering Failure Analysis, vol. 18, pp. 47-51, 2011.

[6] Ebrahimnia M., Malek Ghaini F., Gholizade Sh., Salari M.: Effect of cooling rate and powder characteristics on the soundness of heat affected zone in powder welding of ductile iron, Materials and Design, vol. 33, pp. 551-556, 2012. 